\title{
TRAuMAATTISEN MENETYKSEN KOKENEEN IHMISEN KOHTAAMINEN TUTKIJANA JA SOSIAALITYÖNTEKIJÄNÄ
}

\author{
Hanna Kiuru: VTT, TKI-lehtori, Humanistinen ammattikorkeakoulu, Turku \\ hanna.kiuru@humak.fi
}

Janus vol. 26 (3) 2018, 247-255

\section{JOHDANTO}

Vuorovaikutus niin tutkimushaastattelun kuin auttamistyönkin viitekehyksessä sisältää kohtaamista monella tasolla, mikäli tilanne on onnistunut. Erilaisiksi tasoiksi voi esittää puheen, paikan ja ajan kautta välittyvän yhteyden, kokemuksellisuuden sekä ruumiillisuuden. Tutkija tarvitsee onnistuneen kohtaamisen tuottaakseen tietoa. Ammatillisessa kehyksessä asiakkaan kokemus kohdatuksi tulemisesta on edellytys tuen tavoittamiselle. Edellä mainittuun kiinnittyy myös yhteiskunnallisesti merkittävä palvelujen vaikuttavuusnäkökulma.

Kohtaamisen ulottuvuudet ovat moninaiset ja niihin kiinnittyvät kysymykset ovat olleet viime aikoina esillä tutkimuksellisesti ja ammatillisesti eri tulokulmista. Esimerkiksi Tuija Koivunen ja Hanna Ylöstalo (2017) ovat jäsentäneet puheenvuorossaan tutkijan ja haastateltavan ruumiillisen kohtaamisen merkitystä haastattelutilanteessa. Pirjo Lehtovuori (2018) on puolestaan esittänyt tutkimuksessaan, että psykoterapeutin ominaisuudet vaikuttavat hoidosta saatavaan hyötyyn; terapeutin eläytymiskyky on merkityksellistä ja potilaalle tulee välittyä tunne läsnäolosta. Lastensuojelun kontekstissa on viitattu systeemiseen toimintamalliin, joka tukee asiakkaan kokemusta osallisuudesta ja kuulluksi tulemisesta rakentaen onnistunutta kohtaamista (esim. Lupa auttaa 2018). Tässä puheenvuorossa otan osaltani kantaan kysymykseen kohtaamisesta yhdistäen tutkimuksellisen ja sosiaalityön ammatillisen näkökulman.

Teksti perustuu väitöstutkimukseeni "Tragedian tarina. Nuoren itsemurhaan päättynyt elämä vanhemman kertomana", jossa tarkastelin suomalaisnuorten itsemurhia teon inhimillisen ja sosiaalisen ulottuvuuden näkökulmasta. Tutkimus edustaa narratiivista haastattelututkimusta, johon osallistui 11 äitia ja kolme isää, jotka kertoivat kuolleen lapsensa elämänkulusta. (Kiuru 2015.) Puheenvuoron kirjoitan tutkijana ja sosiaalityöntekijänä.

Tutkimuksen haastattelutilanteissa olin tietoa tavoitteleva tutkija, mutta sosiaalityöntekijän koulutustaustani vaikutti orientaatioon, jolla haastatteluihin asettauduin. Viehätyin Koivusen ja Ylästalon (2017) ilmaisusta, että tutkija voi ruumillaan viestiä haastateltavalle tavoilla, jotka eivät sinällään lukeudu ammatilliseen tutkijarooliin. Heidän esityksessään on yhtymäkohtia siihen, miten katson koulutustaustan vaikuttaneen haastatteluiden muovautumiseen läsnäolon kautta.

Tekstin lähtökohtana on näkemykseni, että aineistonkeruuprosessi on- 
nistui tarkoituksenmukaisesti, koska haastatteluissa toteutui kohtaaminen. Tutkimusprosessin myötä sain oppimiskokemuksia ja ajatuksia, mikä rakensi onnistuneita kohtaamisia ja mahdollisti sen, että osallistuminen jäi vanhemmille ehkä merkityksellisenä mieleen. Huomauttava toki on, että vanhemmat valitsivat tutkimukseen osallistumisen, koska he arvioivat sen palvelevan omaa suru- ja selviytymisprosessiaan. Tämä on vaikuttanut siihen, millaiseksi kokemukseksi osallistuminen on heille muodostunut.

Sosiaalityöntekijänä katson, että haastatteluiden kohtaamistilanteissa oli läsnä elementtejä, jotka ovat merkityksellisiä myös psykososiaalisessa tuessa. Tutkimukseni keskeisenä tuloksena puolestaan oli, että psykososiaalisen toteutuminen on oleellinen palanen palvelujärjestelmässä, että kokemus kohdatuksi tulemisesta mahdollistuu (Kiuru 2015). Näin on mielekästä pysähtyä tarkastelemaan, miten kokemusta kohdatuksi tulemisesta voisi rakentaa. Pyrin esittämään oman näkemykseni tutkimusprosessiin kiinnittyvien kokemusten ja vanhempien kertomusten tulkintojen kautta. Pohjustan vastaustani nostamalla esiin sisältöjä, jotka ovat vaikuttaneet haastatteluiden rakentumiseen, sekä vanhempien kokemuksia kohtaamisista palvelujärjestelmässä nuoren ja vanhemman kannalta.

Puheenvuoro jäsentyy muutaman temaattisen kokonaisuuksien ympärille: kuvaan lyhyesti tämän tekstin kannalta oleellisia tutkimustyöni lähtökohtia, tuon esiin kokemuksiani sensitiivisestä kohtaamisesta toteutuneiden haastattelutilanteiden kautta,jäsennän kokemustiedon hyödyntämisen ehtoja ammatti- käytäntöjen kehittämisessä kiinnittäen ne työni tutkimusasetelmaan ja esitän tulkintojani psykososiaalisen tuen asemasta palvelujärjestelmässä. Päätän tekstin näkemykseeni, miten rakentaa kokemusta kohdatuksi tulemisesta.

\section{LÄHTÖKOHDISTA - TRAgEDIAN TARINA}

Väitöstutkimukseni tutkimustehtävänä oli itsemurhan tehneen lapsen vanhempien subjektiivisten kokemusten tavoittaminen narratiivisen haastattelun keinoin. Yhden tutkimuskysymyksen tarkoituksena oli selvittää, miten auttamistyö merkityksellistyi vanhempien kertomuksissa. (Kiuru 2015.) Puheenvuoron pohdinnat kokemustiedon ja psykososiaalisen tuen merkityksestä ammatillisessa työssä kiinnittyvät erityisesti kyseisen tutkimuskysymyksen kautta syntyneisiin tulkintoihin.

Haastatteluiden myötä on muodostunut kerronnallinen aineisto, joka kertoo keskiluokkaisten nuorten itsemurhaan päättyneestä elämästä heidän vanhempiensa tulkitsemana. Nuoret olivat kuollessaan 15-31-vuotiaita, ja heistä yhdeksän oli poikaa ja viisi tyttöä. Haastatteluajankohtana kuolemasta oli vähimmillään puoli vuotta ja pisimmillään 26 vuotta. Analyysin ja tulkinnan kohteena oli surevan ja syyllisyyden kuormittaman vanhemman yhdessä tutkijan kanssa rakentama kertomus nuoren elämästä. Narratiivisuus, sisällönanalyysi ja elämäkerrallinen ote olivat analyysin lähtökohtana. (Kiuru 2015.)

Toteutin haastattelut yhden kysymyksen haastatteluna ja sovelsin niissä Schützen (1977) elämäkerrallis-ker- 
ronnallisen haastattelun rakenteellista ideaa (ks. Hyvärinen \& Löyttyniemi 2005, 194-198). Esitin jokaiselle vanhemmalle ohjevirkkeen, jonka avulla pyysin häntä kertomaan lapsensa elämäntarinan:

Haluaisin sinun kertovan minulle lapsesi elämäntarinan, kaikkine tapahtumineen ja kokemuksineen, jotka ovat sinulle tärkeitä. Voit aloittaa, mistä haluat, ja käyttää aikaa niin paljon kuin tarvitset. Kuuntelen sinua tässä alussa keskeyttämättä. Teen vain joitakin muistiinpanoja myöhempää keskustelua varten, älä anna sen häiritä. (Kiuru 2015.)

Avaamatta analyysiprosessia tässä yhteydessä sen enempää, mainittakoon, että juonellistamisen avulla vanhempien kertomuksista oli löydettävissä menetetyn nuoren elämäntarina, tragedian tarina ja vanhemman oma selviytymistarina (Kiuru 2015; ks. juonellistamisesta Polkinghorne 1988, 35; 1995, 13-16).

Toteuttamani haastatteluote on ollut vanhemmille vaativa. Päävastuu kerronnasta on asettunut vanhemmalle. Traumaattisista kokemuksista kertominen on puolestaan nostanut tutkijan vastuun tilanteen kulusta ja roolin rohkaisevana kuulijana keskiöön. Ylipäätään sensitiivisissä aiheissa korostuvat tunteiden merkitys tiedon rinnalla ja myös tutkijan eettinen vastuu (Laitinen \& Uusitalo 2007). Tunteiden rooliin ja tutkijan vastuuseen kiinnittyvät myös syyt, joiden vuoksi halusin toteuttaa aineistonkeruun haastatteluina ja nimenomaan kasvotusten. Halusin yrittää ymmärtää muistelutyön vanhemmassa herättämiä tunteita ja olla toisaalta läsnä,jos vanhempi olisi tilanteessa minulta jotakin tuekseen tarvinnut (Kiuru 2015). Valintaa perusteli myös sosiaalityöntekijän koulutukseni. Luotin sen tuomaan osaamiseen toteuttaa haastattelutilanteet sensitiivisellä otteella.

Tutkijan eettinen vastuu kohtaamistilanteessa on merkinnyt mielestäni ennen kaikkea herkkyyttä ymmärtää, milloin kokemuksista kertominen on tehnyt niin kipeää ja aiheuttanut sellaista kohtuutonta tuskaa, että vanhempaa on tullut auttaa kertomuksen juonesta pois (Kiuru 2015, 88; ks. Granfelt 1998, 40). Kohtaamistilanne on edellyttänyt myös luottamusta. Tutkimukseen osallistujien ja tutkijan välisen luottamuksen rakentumisen perustaksi voidaan esittää luotettavuus, avoimuus ja suvaitsevaisuus (Laitinen 2004, 69). Pyrin edistämään kyseisiä ulottuvuuksia muun muassa huomioimalla aineistonkeruuprosessissa vanhempien käytännön toiveita kattavasti ja kertomalla mahdollisimman avoimesti tutkimukseni lähtökohdista sekä myös itsestäni vanhempien niin toivoessa.Vaikka kysymys syyllisyydestä (ks. Kiuru 2017) oli vanhempien puheessa vahvasti läsnä, pyrin korostamaan, etten minä asettanut syyllisyyttä vanhempaan millään tavoin. Jotta vanhemmat selviytyivät vaativasta haastatteluotteesta, on se mielestäni merkinnyt, että luottamus oli rakentunut välillemme jollakin tasolla.

Narratiivisuus tutkimuksessa vs. narratiivinen terapia/menetelmät

Tutkimus- ja terapiatyöhön liittyvien tavoitteiden eron jäsentäminen on ollut merkityksellistä niin haastateltavien kuin tutkijan kannalta. Joskin niiden toisiinsa kietoutuminen on mahdollistanut sensitiivisen kohtaamisen ja sensitiivisyyden toteutumisen. Tavoitteiden ero määrittää myös sitä, millainen rooli ja vastuu tutkijalla on tutkimustyössä ja 
toisaalta ammattilaisella auttamistyön kehyksessä.

Narratiivisen tutkimuksen tavoitteena on ymmärryksen lisääminen tutkimuskohteena olevasta ilmiöstä, kun taas narratiivisen terapian (/menetelmien) tavoitteena on saada aikaan eheyttäviä muutoksia kertojan elämässä (Romanoff 2005, 250). Puhumisen terapeuttinen ulottuvuus oli kylläkin haastatteluissa vahvasti läsnä (Kiuru 2015; 2017). Usealla vanhemmalla kerronnan eheyttävä vaikutus oli etukäteisoletuksena, jolloin se on ollut myös osittaisena osallistumisen syynä.Tutkijana, unohtamatta taustalla olevaa sosiaalityöntekijän koulutustani, kuvaisin haastatteluiden toteutuneen terapeuttisesti painottuneella vuorovaikutuksella siten, että ensisijaisena ja kummankin osapuolen tunnustamana tavoitteena on ollut yhteinen tiedontuottamisen prosessi. Narratiivinen tutkimus mahdollistaa sen, että haastateltavan ja tutkijan yhdessä rakentama kertomus lisää paitsi kertojan myös tutkijan ja ympäristön ymmärrystä tutkimuskohteena olevasta ilmiöstä (Romanoff 2005, 250).

Kokonaisuudessaan narratiivisuus palveli vanhempien muistoja kunnioittavaa otetta ja mahdollisti heille oman selviytymistarinan rakentamisen. Alla on ote keskustelusta, jonka kävimme yhden vanhemman kanssa varsinaisen haastatteluosuuden jälkeen. Keskustelu kuvastaa haastattelun terapeuttisia ulottuvuuksia. Palaan tekstin lopussa lyhyesti siihen, mikä voisi olla narratiivisten menetelmien arvo psykososiaalisessa työssä.

Aika jännä, miten pieni prosentti loppujen lopuksi tämmöiseenkin [tutkimuk- seen] pääsee mukaan. Jos ajattelee, että Suomessa on kymmeniä tuhansia, meitä vastaavassa tilanteessa olevia ihmisiä. Että miten itse siitä onkaan selvinnyt. Kyllä mä niin kuin tähänkin [haastatteluun] tavallaan, pystyin tulemaan tilanteeseen, kun tiesin, ettei tähän kuole. ((Vanhempi hymähtää.)) Elikkä tavallaan, onhan tämä ainutlaatuinen mahdollisuus tavallaan saada puhua. H.K.: Minua lämmittää kovasti, jos näin ajattelet.

Ulkopuoliselle, joka on tavallaan vähän terapiaa, vaikka et sä mikään terapeutti ole. On se terapiaa kaikille meille, ketkä pääsee puhumaan tästä. Se on sulle käynyt varmaan selväksi. Katso, aurinko paistaa. ((Aurinko rupeaa paistamaan ikkunasta.))

\section{Kerronnan motiivit ja merkitykset}

Vanhemman kerronnan motiivit raamittivat haastattelutilannetta. Kerronnan motiivien ja tavoitteiden tiedostaminen on merkityksellistä myös psykososiaalisessa työssä, kun kohtaamistilanteita sävyttää traumaattinen elämäntilanne. Yksilön kriisiprosessin kulloinenkin vaihe vaikuttaa toiminnan taustalla oleviin tavoitteisiin.

Vanhempien osallistumisen syyt jakautuivat pääpiirteittäin kahtaalle. Osa vanhemmista halusi osallistua tutkimukseeni nimenomaan nuoren takia. Toisten syyt puolestaan liittyivät korostuneesti omiin lähtökohtiin ja jäljellejääneen perheen selviytymiseen. Uskoakseni molemmat motiivit liittyivät jokaisen vanhemman kerrontaan, mutta vanhemmasta riippuen painotukset vaihtelivat. Minulle syntyi vaikutelma, että mikäli vanhempi oli saanut etäi- 
syyttä nuoren menetystä seuranneista tunteista, osallistumisen syyt ja kerronnan saamat merkitykset liittyivät vahvasti jäljellejääneisiin. Sen sijaan jos vanhemman selviytymisprosessi oli kovin keskeneräinen, osallistumisen syyt ja kerronnan merkitykset liittyivät hallitsevasti nuoreen. Tuolloin vanhempi halusi jakaa omia kokemuksiaan nuoren elämästä ja kertoa tämän kuoleman jälkeen muodostuneesta uudesta ymmärryksestään. Tiedon jakaminen vanhemmille ja nuorten itsemurhien ehkäisytyön edistyminen määrittyivät kerronnan ensisijaiseksi motiiviksi ja merkitykseksi. (Kiuru 2015, 75.)

Kun vanhempi rakensi kertomustaan omista lähtökohdistaan ja jäljellejäänyttä perhettään ajatellen, kerronnan merkitys liittyi ensisijaisesti jäljellejääneiden auttamisjärjestelmän kehittämiseen. He toivoivat tutkimukseni vaikuttavan siihen, että järjestelmästä korjaantuisi epäkohtia, joita he olivat joutuneet kohtaamaan menetyksen jälkeen. (Kiuru 2015, 75; ks. Uusitalo 2006, 88.) Tulkintani vanhempien osallistumisen syistä on perustunut heidän kertomaansa ja omiin tuntemuksiini. Huomattava on, että osallistumisen taustalla on saattanut olla myös motiiveja, joista vanhemmat eivät ole olleet itsekään tietoisia tai joita he ovat pyrkineet salaamaan päästäkseen mukaan tutkimukseen. Osallistuminen on voinut näyttäytyä esimerkiksi väylänä tuoda esiin koettua vihaa ja katkeruutta tai kostaa syyllisiksi määritetyille. (Kiuru 2015, 76.)

\section{Sensititvinen KOHTAAminen}

Keskinäisen yhteyden tunnustelu alkoi jokaisen vanhemman kanssa ennen haastattelua sähköposti- ja/tai puhelinkeskusteluin. Tunnustelun merkitys kiteytyi siihen, että sen avulla rakensimme keskinäistä luottamusta. Vanhemman näkökulmasta tämä tarkoitti mielestäni sitä, että hän halusi testata, mitä ymmärtäisin ja mitä minulle uskaltaisi kertoa. (Kiuru 2015.)

Itse haastatteluissa oli puolestaan läsnä näkymättömiä ja tiedostamattomia sekä näkyviä ja tiedostettuja tilanteen ehtojen tunnusteluja, joiden avulla testasimme jo kertynyttä luottamusta. Se rakentui loppuun asti sille tasolle, jonne sen oli mahdollista yltää. Tunnustelu ilmeni kohtaamisissa katseina, eleinä, haastavina lauseina ja jotain etsivänä ilmapiirinä, minkä rinnalla vanhempi teki minusta määrittelyä ihmisenä ja kuulijana selvittääkseen, mitä kestäisin ja mitä minulla olisi oikeus kuulla. (Kiuru 2015, 71.) Vanhempi saattoi esimerkiksi kertoa hyvinkin suorasanaisesti omasta hoitohistoriastaan ja itsetuhoisista ajatuksistaan, joita hänellä oli ollut lapsen kuoleman jälkeen. Hän halusi ikään kuin nähdä, miten reagoin kuulemaani. Kokonaisuudessaan tunnustelun merkitykseen sisältyi myös se, että puolin ja toisin oli luvallista myöntää oma epävarmuus, joka tilanteessa oli läsnä.

Haastatteluihin liittyi runsaasti tekijöitä, jotka tuli tutkijana ja kuulijana ratkaista. Mietin paljon, miten lapsen elämästä ja kuolemasta voi puhua, ja mitä sanoja saa käyttää. Yhteisen kielen löytäminen on ollut tutkimuksellinen ehto ymmärryksen lisäämiseksi, mutta 
se on ollut myös merkityksellistä kohtaamistilanteen eettisyys huomioiden. Moni vanhempi nosti kielen ratkaisevaksi tekijäksi ihmissuhteissaan keskinäisen yhteyden syntymisen kannalta menetyksen jälkeen. He toivoivat osakseen suoruutta ja välittömyyttä arvottaen teennäisyyden loukkaavaksi. (Kiuru 2015.)

Yhteisen kielen rinnalla katseiden merkitys on ollut suuri. Toiset vanhemmat hakivat tiiviisti katsekontaktia kerronnan aikana, minkä tulkitsin keinoksi etsï turvaa. Toiset puolestaan käänsivät katsettaan selkeästi toisaalle ehkä ottaakseen etäisyyttä ja hallitakseen tunteitaan. Paikoin katsekontaktin säilyttäminen tuntui minusta vaikealta, koska silloin vanhemman tuska välittyi vahvemmin. En kuitenkaan kääntänyt katsettani pois, jos vanhempi sitä etsi. (Kiuru 2015, 73.)

Koska vanhemmat kertoivat lapsensa elämäntarinaa, kertomukset sisälsivät paljon onnellisia muistoja, jolloin haastattelussa oli läsnä iloa ja naurua. Lähtökohtaisesti oli kuitenkin selvää, miten lapsen elämäntarina tulisi päättymään, joten tuska hiipi hiljalleen paikalle vanhemman kerronnan edetessä. Vanhemman suru ja ikävä sekä syyllisyyden, vihan ja häpeän tunteet olivat vuorotellen tai rinnakkain tilanteessa läsnä. (Kiuru 2015, 73; ks. ruumiillisesti koetut tunteet Koivunen \& Ylöstalo 2017, 240.) Liikutuin kohtaamisissa usein, enkä pyrkinyt peittelemään sitä.

Kaikkiin edellä kuvaamiini seikkoihin sisältyy ajatus, että oman persoonan käyttö tutkijan työkaluna (ks. ruumiin käyttö tutkijan työvälineenä Koivunen \&Ylöstalo 2017, 241), ja ylipäätään toi- sen ihmisen muistoja kunnioittavana kuulijana, on ollut ratkaisevassa asemassa kohtaamisten kannalta. Osoitukseksi luottamuksen rakentumisesta määritän, että moni vanhempi halusi mennä kerronnassaan läpi kipeimmän, vaikka yritin suunnata tarinaa niissä hetkissä toisaalle (Kiuru 2015, 88). Kyseiset tarinan episodit eivät olleet tutkimusaineiston kertymisen kannalta oleellisia, mutta niillä oli selkeästi merkitystä vanhemman muistelutyölle, ja vanhempi määritti minut hetkissä kelvolliseksi kuulijaksi. Moni vanhempi kertoi haastattelutilanteessa myös sellaisia asioita, joita he eivät olleet aiemmin muille kertoneet, tai he halusivat kertoa nuoren varsinaisen elämäntarinan ulkopuolelta jotain sellaista, minkä sovimme jäävän vain meidän väliseksi.

\section{PalvelujärJestelmän Kehittäminen KOKEMUSTIETOON PERUSTUEN}

Auttamistyöhön kiinnittyvät pohdinnat sisältävät erittelyssäni kolme näkökulmaa. Ensinnäkin ne sisältävät vanhemman kokemuksia, miten oma lapsi on palvelujärjestelmässä kohdattu, ja toisaalta vanhemman näkemyksiä siitä, miten hänet on kohdattu lapsen rinnalla palvelujärjestelmässä sekä lapsen kuoleman jälkeen surevana vanhempana mahdollisesti muun perheen kanssa. Jäsennysten pääpaino on kielteisissä kokemuksissa, koska ne korostuivat kertomuksissa tutkimuksen tehtävänasettelun vuoksi. Se ei poissulje sitä, etteikö vanhemmilla olisi ollut myös positiivisia kokemuksia kohtaamisissa palvelujärjestelmässä tai ylipäätään suhteissa.

Palvelurakenteet ja ammattikäytännöt suunnitellaan ja toteutetaan yleensä 
viralliseen tietoon nojaten. Rinnalle tarvitaan kuitenkin kokemustietoa ammatillisen työskentelyn kehittämiseksi. (Kiuru 2015, 253; ks. Hänninen ym. 2005.) On syytä huomauttaa kokemustiedot hyödyntämisen ehdoista tutkimuksessani. Vanhemmat ovat rakentaneet tarinansa siten, kuin he ovat kyenneet. Heidän on täytynyt rakentaa tarina itselleen hyväksyttäväksi todellisuudeksi, jotta elämä menetyksen jälkeen mahdollistuu. Tutkimuksella ei ole ollut tarkoitus tuottaa pääsyä yhteen totuuteen ja todellisuuteen, vaan sen kautta on jäsentynyt tietyssä tilanteessa kerrottuja kokemuksellisia tarinoita, joita voidaan kuitenkin hyödyntää tutkivalla otteella ammattikäytäntöjen kehittämisessä. (Kiuru 2015.)

Kokoavasti vanhempien hoitokontakteihin liittyneitä kokemuksia hallitsi negatiivinen, syyllisyyteen ja syyttämiseen perustuva sävy. Kritiikki suuntautui erityisesti palvelujärjestelmään ja auttamistyötä toteuttaneiden tahojen toimintaan. Nuoren elämään paikantuen kohtaamisen konteksteina olivat olleet hallitsevasti julkisen sektorin erikoissairaanhoidon psykiatriset poliklinikat ja psykiatrinen osastohoito nuoren oirehdinnan vuoksi. Masennus- tai ahdistushäiriödiagnoosi oli vaikuttanut nuoren kohtaamiseen hoitokontaktissa siten, että häntä oli tarkasteltu diagnoosin ilmaiseman viiteryhmän edustajana kokonaisvaltaisen yksilön sijaan. Nuori oli ikään kuin kadotettu masennuksen tai ahdistuksen taakse. (Kiuru 2015.)

Kertomuksissa korostuivat kokemukset kohtaamistilanteiden näennäisyydestä ja siitä, ettei hoito ollut tavoittanut nuorta tämän eläessä, tai tuki surevaa vanhempaa nuoren kuoleman jälkeen.
Kokemukset yksinjäämisestä ja luottamuksen katoamisesta suhteessa palvelujärjestelmään olivat osa perheiden tragediaa niin nuoren elämän kuin kuoleman jälkeisessä ajassa. (Kiuru 2015.) Seuraavaan otteeseen kiteytyy yhden vanhemman ajatus siitä, miten jäljellejäänyt perhe oli joutunut järjestelmän hylkäämäksi menetyksen jälkeen.

Kukaan ei tarjonnut yhtään mitään kenellekään.

Asetelman voi toki kääntää myös toisin päin. Työntekijän on siedettävä omia kielteisiä tunteitaan tai asiakkaan käytöstä, jonka määrittää epämieluisaksi. Työntekijän on jaksettava turhautumista tilanteissa, joissa asiakas osoittaa, ettei halua sitoutua kontaktiin tai mitätöi työntekijän osaamista. Traumaattisen menetyksen kohdanneet voivat olla myös erityisen haastava asiakasryhmä ammattilaisille sen vuoksi, että he kokevat, ettei tarvitse sietää toiselta osapuolelta itselle epämieluisaa käytöstä suuren menetyksen vuoksi (Kiuru 2015).

\section{Psykososiaalisen tuen merkitys ja asema}

Vanhempien kertomukset osoittivat, että psykososiaalinen tuki oli palanen, jota perheiden tilanteissa olisi usein tarvittu kohtaamisen näkökulmasta. Vaikkakin kontekstina olisi lääketieteelliseen asiantuntemukseen pohjautuva toimintaympäristö, hoidolliseen viitekehykseen perustava kohtaaminen ei yksinään riitä. Kun psykososiaaliseen kehykseen perustuva asiantuntemus kulkee tilanteissa rinnalla, mahdollistuu ymmärtämiseen pyrkivä ote sekä sosiaalisen ja psyykkisen näkökulman huomioiminen. (Kiuru 2015.) 
Käytännön työn kannalta katson, että yksilölle tulisi tarjota herkästi mahdollisuus elämäntapahtumien terapeuttissävytteiseen työstämiseen. On yksilöllistä, mikä on kipeä kokemus, ja mihin tarvitsee tukea. Jos käsittelyn mahdollisuutta ei tarjota, saattaa syntyä kokemus torjutuksi tulemisesta. Pienillä asioilla voi olla suuri merkitys ja vaikutus yksilön selviytymiselle kuormittavissa elämäntilanteissa. Hädän keskellä kokemus asiantuvasta ammattiauttajasta, luottamisen mahdollisuudesta ja järjestelmän toimivuudesta on tärkeä (Kiuru 2015).

\section{Miten RAKentaA KOKEMUSTA KOHDATUKSI TULEMISESTA?}

Asetin puheenvuoron alussa tavoitteeksi vastata kysymykseen, miten kokemusta kohdatuksi tulemisesta voisi rakentaa. Kiteytän näkemykseni tutkijana ja sosiaalityöntekijänä seuraavasti tutkimusprosessin mahdollistaman oppimisen ja vanhempien kertomusten valossa: toisen kokemusta ei voi koskaan täysin ymmärtää ja tavoittaa, mutta sitä voi pyrkiä ymmärtämään empaattisesti. Läsnä tulee olla omana itsenään ja aidosti. Tällöin mahdollistun kokemus kohdatuksi tulemisesta. Tapa, jolla kuhunkin kohtaamiseen tulee asettautua, on yksilöllinen.

Lisäksi haluan korostaa narratiivisten menetelmien hyödynnettävyyttä psykososiaalisessa työssä. Niiden käyttöarvo perustuu mielestäni erityisesti siihen, että ne mahdollistavat kipeistä asioista kertomisen, niiden tarkastelun ja uudenlaisen ymmärryksen rakentumisen sekä omien voimavarojen näkemisen (Kiuru 2015). Narratiivisten menetelmien voi ajatella olevan sovellettavissa mielekkäästi sosiaalityön viitekehyksessä, jossa asiantuntijuuden ja ammatillisuuden ydintä on empaattinen läsnäolo, kuuntelemisen taito ja tilan luominen yksilölliselle muutosprosessille.

Päätän tekstin otteeseen yhden vanhemman väitöspäivänä minulle antamasta onnittelukortista. Ajattelen, että ainakin kyseisen vanhemman kohdalla tutkimukseen osallistuminen oli muodostunut osaksi hänen selviytymistarinaansa. Sen voi tulkita edellyttäneen, että olemme kohdanneet toisemme.

\section{Kevyt olo.}

\section{Kirjallisuus}

Granfelt, Riitta (1998) Kertomuksia naisten kodittomuudesta. Toimituksia 702. Helsinki: Suomalaisen Kirjallisuuden Seura.

Hyvärinen, Matti \& Löyttyniemi, Varpu (2005) Kerronnallinen haastattelu. Teoksessa Johanna Ruusuvuori \& Liisa Tiittula (toim.) Haastattelu - tutkimus, tilanteet ja vuorovaikutus. Tampere: Vastapaino, 189-222.

Hänninen, Sakari \& Karjalainen, Jouko \& Lahti, Tuukka (2005) (toim.) Toinen tieto: kirjoituksia huono-osaisuuden tunnistamisesta. Helsinki: Sosiaali- ja terveysalan tutkimus- ja kehittämiskeskus.

Kiuru, Hanna (2015) Tragedian tarina. Nuoren itsemurhaan päättynyt elämä vanhemman kertomana. Sarja C, Scripta lingua Fennica edita, osa 404. Turku: Turun yliopisto.

Kiuru, Hanna (2017) 'Älkää jättäkö näitä ihmisiä yksin.' Syyllisyyden tahraama vanhemman selviytymistarina lapsen itsemurhan jälkeen. Perheterapia 33 (2), 5-20.

Koivunen, Tuija \& Ylöstalo, Hanna (2017) Tutkimushaastattelu ruumillisena kohtaamisena. Janus 25 (3), 240-247.

Laitinen, Merja (2004) Häväistyt ruumiit, rikotut mielet. Tutkimus lap- 
sina läheissuhteissa seksuaalisesti hyväksikäytettyjen naisten ja miesten elämästä. Tampere:Vastapaino.

Laitinen, Merja \& Uusitalo, Tuula (2007) Sensitiivisen haastattelututkimuksen eettiset haasteet. Janus 15 (4), 316-332.

Lehtovuori, Pirjo (2018) Psykoterapeutin henkilökohtaisten ominaisuuksien merkitys psykoterapiassa ja niiden vaikutus tuloksellisuuteen identiteettihaastattelun perusteella. Jyväskylä studies in education, psychology and social research 602. Jyväskylä: Jyväskylän yliopisto.

Lupa auttaa (2018) Nuoren kokemus kuulluksi tulemisesta mahdollisti muutoksen. Lupa auttaa! -hanke. https://www. lupaauttaa.fi/uutishuone/nuoren-kokemus-kuulluksi-tulemisesta-mahdollistimuutoksen/ Luettu 21.2.2018.

Polkinghorne, Donald (1988) Narrative Knowing and the Human Sciences. Al- bany: State University of New York Press. Polkinghorne, Donald (1995) Narrative Configuration in Qualitative Analysis. Teoksessa Amos J. Hatch \& Richard Wisniewski (toim.) Life History and Narrative. London: Falmer Press, 5-23. https:// doi.org/10.1080/0951839950080103

Romanoff, Bronna D. (2005) Research as Therapy: The Power of Narrative to Effect Change. Teoksessa Robert A. Neimeyer (toim.) Meaning Reconstruction \& the Experience of Loss. Washington DC: American Psychological Association, 245-257.

Uusitalo, Tuula (2006) Miten päästä yli mahdottoman? Narratiivinen tutkimus itsemurhamenetyksistä. Acta Universitatis Lapponiensis 105. Rovaniemi: Lapin yliopisto. 